\title{
CRUSTACEAN ZOOPLANKTON COMMUNITIES IN CHILOÉ ISLAND COASTAL LAKES $\left(42^{\circ} \mathrm{S}, \mathrm{CHILE}\right)$
}

\author{
BY \\ PATRICIO R. DE LOS RÍOS ESCALANTE ${ }^{1,2,4}$ ) and FATIMA KIES ${ }^{3}$ ) \\ 1) Laboratorio de Ecología Aplicada y Biodiversidad, Escuela de Ciencias Ambientales, Facultad \\ de Recursos Naturales, Universidad Católica de Temuco, casilla 15-D, Temuco, Chile \\ 2 ) Núcleo de Estudios Ambientales, UC Temuco, casilla 15-D, Temuco, Chile \\ 3 ) Department of Earth and Environmental Sciences, Università Degli Studi di Milano-Bicocca, \\ Milan, Lombardy, Italy
}

\begin{abstract}
The lakes of Chiloé Island have a high dissolved organic carbon concentration (known as "humic") and show a connection with brackish water. They also display a high species richness of crustacean zooplankton. The aim of the present study is to characterize the potential factors that explain crustacean species richness in Chiloé Island lakes. To that purpose parameters of the abiotic environment were determined. The results of PCA performed on those data revealed the existence of three lakes with high crustacean species richness that are relatively deep, show high nitrogen concentrations, and are located at relatively high altitude. In contrast, there are two lakes with low species richness, high mineral concentration, and situated at low altitude. One of these lowland lakes gives rise to a river effluent to the sea, and it is connected to the other lake; these observations agree with the results of a performed cluster analysis. Nevertheless, the co-occurrence null model analysis revealed the absence of regulator patterns in species associations, which could be explained to the fact that many of the species occur in most of the lakes. These results are markedly different in comparison to Patagonian lakes of Argentina and Chile that have a low crustacean species number.
\end{abstract}

\section{RÉSUMÉ}

Les lacs de l'île de Chiloé ont une teneur élevée en carbone organique dissous et présentent une connexion avec l'eau saumâtre. Ils présentent également une grande richesse en espèces de crustacés zooplanctoniques. Le but de la présente étude est de caractériser les facteurs potentiels qui expliquent la richesse des espèces de crustacés dans les lacs de l'île de Chiloé. À cette fin, les paramètres de l'environnement abiotique ont été déterminés. Les résultats de l'ACP réalisée à partir de ces données ont révélé l'existence de trois lacs riches en espèces de crustacés, relativement profonds, riches en azote et situés à une altitude relativement élevée. En revanche, il y a deux lacs avec une faible richesse en espèces, une concentration élevée en minéraux et situés à basse altitude. L'un de ces lacs de basse altitude donne naissance à un effluent de rivière vers la mer et est relié à l'autre lac; ces observations

${ }^{4}$ ) Corresponding author; e-mail: prios@uct.cl

(C) Koninklijke Brill NV, Leiden, 2018 
sont en accord avec les résultats d'une analyse de cluster. Néanmoins, l'analyse du modèle nul de co-occurrence a révélé l'absence de modèles de régulation dans les associations d'espèces, ce qui pourrait s'expliquer par le fait que de nombreuses espèces sont présentes dans la plupart des lacs. Ces résultats sont nettement différents par rapport aux lacs de Patagonie d'Argentine et du Chili qui ont un faible nombre d'espèces de crustacés.

\section{INTRODUCTION}

The crustacean communities occurring in Chilean lakes have been studied mainly for Patagonian mountain lakes, and these communities are characterized by their low species richness due to the marked oligotrophy of these sites (De los Ríos-Escalante, 2016). Nevertheless, there are many coastal lagoons between $39^{\circ}$ and $42^{\circ} \mathrm{S}$ (Hauenstein et al., 2002; Villalobos et al., 2003), and of these water bodies, only the lakes on Chiloé Island have been studied from a limnological point of view (Campos, 1997; Villalobos et al., 2003).

The Chiloé Island lakes now have a high dissolved organic carbon concentration [known as "humic"] and show a connection with brackish water. These lakes have undergone marked human intervention, due to alterations in their surrounding basins, due to the establishment of agricultural zones, the settling and development of rural human populations, and through salmon farming activities (Villalobos et al., 2003). Similar results have been reported earlier for northern Patagonian lakes at latitudes between $38^{\circ}$ and $41^{\circ} \mathrm{S}$ (De los Ríos-Escalante, 2016). In this context, under human intervention in the surrounding basins, a transition from oligotrophy to mesotrophy has taken place, with consequent changes that resulted in an increase of the locally present numbers of species in the crustacean zooplankton (Soto \& Zúñiga, 1991; Woelfl, 2007; De los Ríos-Escalante, 2016). Comparable results have been reported for New Zealand, for other Patagonian lakes (Jeppensen et al., 1997), and for central Chilean lagoons located at coastal zones (De los RíosEscalante, 2016).

From another point of view, the lakes on Chiloé Island experience a marked coastal influence due to the presence of river effluents that are directed towards the Pacific Ocean: that is where the rivers of the island discharge their fresh water (and its contents). In this scenario, if a lake is close to the Pacific coast, this lake is under marked marine influence (Villalobos et al., 2003), i.e., stronger winds and brackish water influences. It is probable that such conditions will have, in their turn, an influence on zooplankton community structure. The aim of the present study is to analyse the factors that would affect the numbers of crustacean species in the zooplankton in the lakes of Chiloé Island, based on a re-analysis of data published by Campos (1997) and Villalobos et al. (2003). 


\section{MATERIAL AND METHODS}

Data on the numbers of species in the zooplankton and their morphometrics, as well as chemical data, were obtained from Campos (1997) and Villalobos et al. (2003) for five Chiloé Island lakes: Natri, Cucao, Huillinco, Tepuhueico, and Tarahuín (fig. 1, table I). These data were analysed by us in three steps: first, to determine the main factors explaining the differences between the studied sites, a principal component analysis (PCA) was applied using the software R (R Core Team, 2009), and the HSAUR R-package (Everitt \& Hothorn, 2016).

In the following steps, a species absence / presence matrix was constructed, with the species in rows and the sites in columns (table I, bottom part). The second step consisted of performing a UPGMA cluster analysis, using the Neighbour-joining method for determining potential similarities between sites on the basis of species associations, using the $\mathrm{R}$ package Phangorn (Schliep, 2011). Thirdly, we calculated a Checkerboard score ("C-score"), which is a quantitative index of occurrence that measures the extent to which species co-occur less frequently than expected by chance (Gotelli, 2000). A community is structured by competition when the C-score is significantly larger than expected by chance (Gotelli, 2000; Tondoh, 2006; Gotelli \& Entsminger, 2007; Tiho \& Johens, 2007). From that C-score, we compared co-occurrence patterns with null expectations via simulation. Gotelli \& Ellison (2013) suggested the use of only the statistical null model "Fixed-Fixed", as this is the most robust. In this model, the row and column sums of the original matrix are preserved: thus, each random community contains the same number of species as the original community (fixed column), and each species occurs with the same frequency as in the original community (fixed row). The null model analyses were performed using the package EcosimR version 7.0 (Gotelli \& Ellison, 2013).

\section{RESULTS}

The results revealed a relatively mesotrophic status for three of the five lakes studied on Chiloé Island, i.e., with low mineral concentrations in the lakes Natri, Tarahuín and Tepuhueico; in contrast, there were high mineral concentrations in the lakes Cucao and Huillinco (table I). The results of the PCA showed that the main contributing variables for axis 1 were total dissolved solids, salinity, nitrate, ammonium, organic nitrogen, total nitrogen, orthophosphate, total phosphorus, organic seston, inorganic seston, calcium, magnesium, sodium, potassium, chloride, sulfate, bicarbonate, and alkalinity (table II, fig. 2). Whereas for the second axis, the main contributor variables were maximum depth $\left(\mathrm{Z}_{\max }\right)$, mean depth $\left(\mathrm{Z}_{\text {mean }}\right)$, relative depth $\left(Z_{\text {rel }}\right)$, conductivity, nitrite, colour and turbidity (table II, fig. 2). 


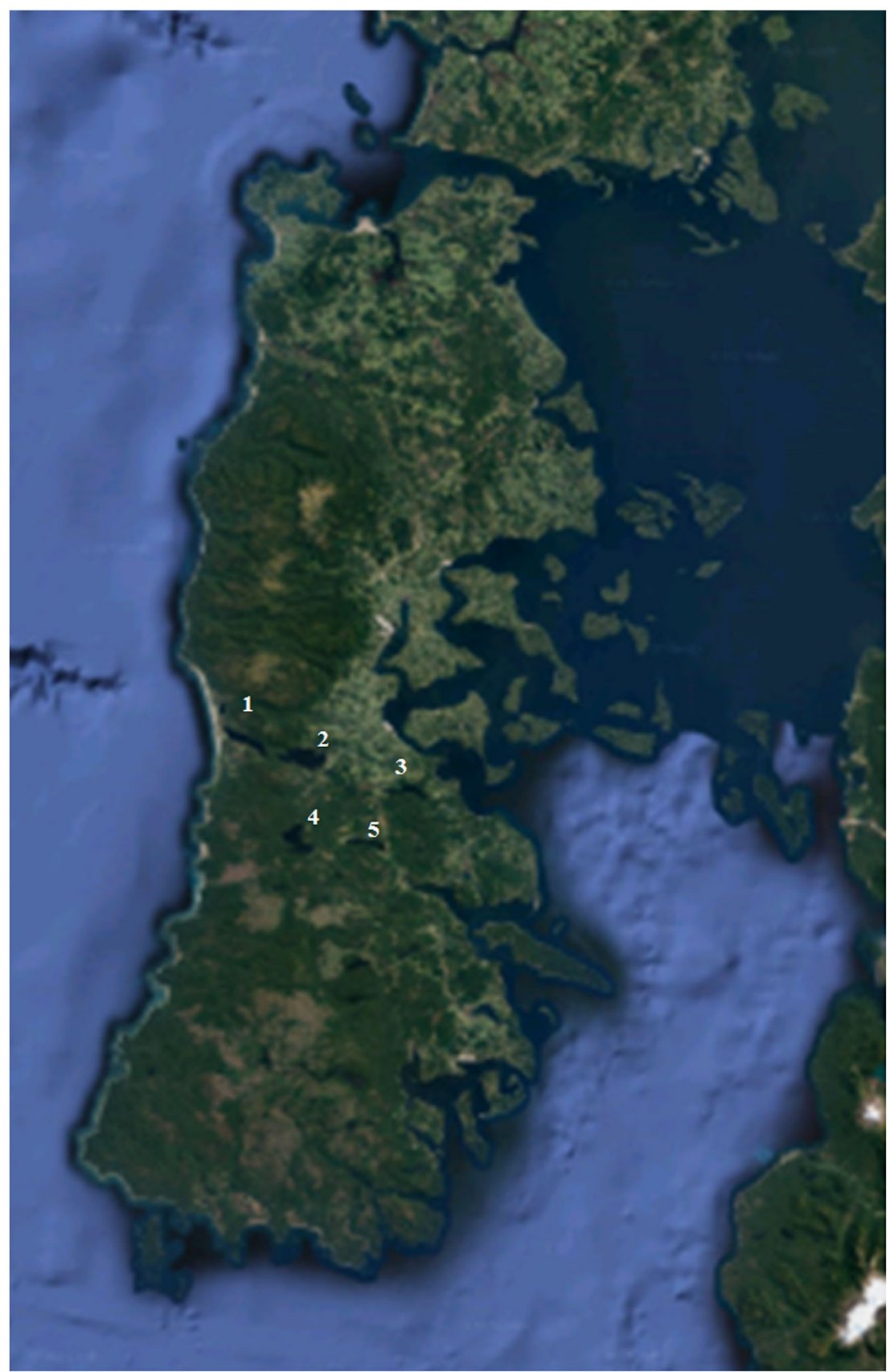

Fig. 1. Map of the studied sites on Chiloé Island, Chile (1: Cucao; 2: Huillinco; 3: Tarahuin; 4: Tepuhueico; 5: Natri). Source: Google Earth: https://www.google.cl/maps/@-42.8693554,-73. $4747229,355972 \mathrm{~m} / \mathrm{data}=! 3 \mathrm{~m} 1 ! 1 \mathrm{e} 3$. 
TABLE I

Geomorphometrics, chemical parameters, and zooplankton species reported for Chiloé Island lakes (cf., Campos, 1997; Villalobos et al., 2003)

\begin{tabular}{|c|c|c|c|c|c|}
\hline & $\begin{array}{l}\text { Lake } \\
\text { Natri }\end{array}$ & $\begin{array}{c}\text { Lake } \\
\text { Tepuhueico }\end{array}$ & $\begin{array}{c}\text { Lake } \\
\text { Taarahuin }\end{array}$ & $\begin{array}{l}\text { Lake } \\
\text { Huillinco }\end{array}$ & $\begin{array}{l}\text { Lake } \\
\text { Cucao }\end{array}$ \\
\hline \multirow[t]{2}{*}{ Latitude/longitude } & $42^{\circ} 47^{\prime} \mathrm{S}$ & $42^{\circ} 47^{\prime} \mathrm{S}$ & $42^{\circ} 43^{\prime} \mathrm{S}$ & $42^{\circ} 40^{\prime} \mathrm{S}$ & $42^{\circ} 38^{\prime} S$ \\
\hline & $73^{\circ} 50^{\prime} \mathrm{W}$ & $73^{\circ} 58^{\prime} \mathrm{W}$ & $73^{\circ} 45^{\prime} \mathrm{W}$ & $73^{\circ} 57^{\prime} \mathrm{W}$ & $73^{\circ} 40^{\prime} \mathrm{W}$ \\
\hline Altitude (m a.s.1.) & 39.0 & 25.0 & 66.0 & 13.0 & 10.0 \\
\hline Volume $\left(\mathrm{km}^{3}\right)$ & 0.273 & 0.128 & 0.170 & 0.395 & 0.127 \\
\hline Surface $\left(\mathrm{km}^{2}\right)$ & 7.8 & 14.3 & 7.7 & 19.1 & 10.6 \\
\hline Maximum depth $\left(Z_{\max }\right)(\mathrm{m})$ & 58.0 & 25.0 & 33.0 & 47.0 & 25.0 \\
\hline Mean depth $\left(Z_{\text {mean }}\right)(\mathrm{m})$ & 35.0 & 9.0 & 22.2 & 20.7 & 12.0 \\
\hline Relative depth $\left(Z_{\text {rel }}\right)(\mathrm{m})$ & 1.8 & 0.6 & 1.1 & 1.0 & 0.7 \\
\hline Colour (Platinum-Cobalt units) & 41.4 & 131.4 & 40.0 & 92.8 & 81.6 \\
\hline Turbidity (mg/l) & 2.8 & 5.3 & 2.8 & 4.3 & 3.9 \\
\hline $\mathrm{pH}$ & 6.4 & 5.8 & 6.7 & 6.9 & 6.8 \\
\hline Conductivity (mS/cm) & 41.4 & 30.2 & 50.9 & 27326.00 & 156858.00 \\
\hline Salinity $(\mathrm{g} / \mathrm{l})$ & 0.10 & 0.1 & 0.10 & 18.9 & 10.4 \\
\hline Total dissolved solids (mg/l) & 43.4 & 31.6 & 52.9 & 942.9 & 732.8 \\
\hline Oxygen (mg/l) & 8.5 & 9.5 & 8.4 & 3.5 & 6.0 \\
\hline $\mathrm{N}-\mathrm{NO}_{3}-(\mu \mathrm{g} / \mathrm{l})$ & 565.9 & 445.0 & 154.4 & 3527.5 & 2154.2 \\
\hline $\mathrm{N}-\mathrm{NO}_{2}^{-}(\mu \mathrm{g} / \mathrm{l})$ & 2.1 & 6.3 & 1.9 & 8.0 & 24.8 \\
\hline $\mathrm{N}-\mathrm{NH}_{4}+(\mu \mathrm{g} / \mathrm{l})$ & 9.3 & 13.9 & 9.3 & 1470.0 & 123.5 \\
\hline Organic nitrogen $(\mu \mathrm{g} / \mathrm{l})$ & 165.0 & 144.0 & 150.7 & 5138.5 & 2448.9 \\
\hline $\mathrm{P}-\mathrm{PO}_{4}{ }^{3-}(\mu \mathrm{g} / \mathrm{l})$ & 5.7 & 2.8 & 3.4 & 88.3 & 16.9 \\
\hline Total phosphorus $(\mu \mathrm{g} / \mathrm{l})$ & 23.6 & 15.9 & 23.5 & 496.9 & 223.0 \\
\hline Organic seston $(\mathrm{mg} / \mathrm{l})$ & 1.1 & 1.5 & 1.7 & 2.2 & 1.8 \\
\hline Inorganic seston $(\mathrm{mg} / \mathrm{l})$ & 0.5 & 0.4 & 1.0 & 5.6 & 3.8 \\
\hline Calcium (Ca, mg/l) & 1.7 & 1.4 & 3.3 & 181.5 & 111.9 \\
\hline Magnesium (Mg, mg/l) & 1.2 & 0.9 & 1.6 & 562.2 & 301.5 \\
\hline Sodium (Na, mg/l) & 4.7 & 4.4 & 4.8 & 1386.6 & 1300.0 \\
\hline Potassium (K, mg/l) & 0.7 & 0.6 & 0.9 & 211.0 & 115.7 \\
\hline Chloride (Cl, mg/l) & 8.8 & 8.0 & 8.4 & 11473.0 & 7055.0 \\
\hline Sulfate $\left(\mathrm{SO}_{4}{ }^{2-}, \mathrm{mg} / \mathrm{l}\right)$ & 28.0 & 62.2 & 23.7 & 19241.1 & 12839.0 \\
\hline Bicarbonate $\left(\mathrm{HCO}_{3}^{-}, \mathrm{mg} / \mathrm{l}\right)$ & 12.9 & 9.8 & 22.5 & 183.0 & 72.1 \\
\hline Alkalinity & 0.2 & 0.2 & 0.4 & 3.0 & 1.2 \\
\hline \multicolumn{6}{|l|}{ Presence } \\
\hline \multicolumn{6}{|l|}{ Cladocera } \\
\hline $\begin{array}{l}\text { Ceriodaphnia dubia Richard, } \\
1894\end{array}$ & $X$ & $\mathrm{X}$ & & $X$ & \\
\hline Daphnia pulex Leydig, 1860 & & & $\mathrm{X}$ & & \\
\hline $\begin{array}{l}\text { Diaphanosoma chilense Daday, } \\
\quad 1902\end{array}$ & & $\mathrm{X}$ & $\mathrm{X}$ & $\mathrm{X}$ & \\
\hline $\begin{array}{l}\text { Chydorus sphaericus (O.F. } \\
\text { Müller, 1785) }\end{array}$ & $X$ & & $\mathrm{X}$ & & \\
\hline Alona sp. & & & & $\mathrm{X}$ & $X$ \\
\hline $\begin{array}{l}\text { Neobosmina chilensis (Daday, } \\
\text { 1902) }\end{array}$ & $X$ & $X$ & $X$ & & $X$ \\
\hline
\end{tabular}


TABLE I

(Continued)

\begin{tabular}{|c|c|c|c|c|c|}
\hline & $\begin{array}{l}\text { Lake } \\
\text { Natri }\end{array}$ & $\begin{array}{c}\text { Lake } \\
\text { Tepuhueico }\end{array}$ & $\begin{array}{c}\text { Lake } \\
\text { Taarahuin }\end{array}$ & $\begin{array}{c}\text { Lake } \\
\text { Huillinco }\end{array}$ & $\begin{array}{l}\text { Lake } \\
\text { Cucao }\end{array}$ \\
\hline $\begin{array}{l}\text { Ilyocryptus sp. } \\
\text { Copepoda }\end{array}$ & & & $\mathrm{X}$ & & \\
\hline $\begin{array}{l}\text { Boeckella gracilipes Daday, } \\
1901\end{array}$ & $\mathrm{X}$ & $\mathrm{X}$ & $X$ & & \\
\hline $\begin{array}{l}\text { Tumeodiaptomus diabolicus } \\
\text { (Brehm, 1935) }\end{array}$ & & $\mathrm{X}$ & & $\mathrm{X}$ & $\mathrm{X}$ \\
\hline $\begin{array}{l}\text { Mesocyclops longisetus } \\
\quad \text { (Thiébaud, 1912) }\end{array}$ & $\mathrm{X}$ & $\mathrm{X}$ & $X$ & $\mathrm{X}$ & \\
\hline $\begin{array}{l}\text { Tropocyclops prasinus (Fischer, } \\
\text { 1860) }\end{array}$ & $X$ & $X$ & $X$ & $X$ & $X$ \\
\hline Cyclops sp. & & & $X$ & & \\
\hline Harpacticoida indet. & $X$ & & $X$ & $X$ & $X$ \\
\hline
\end{tabular}

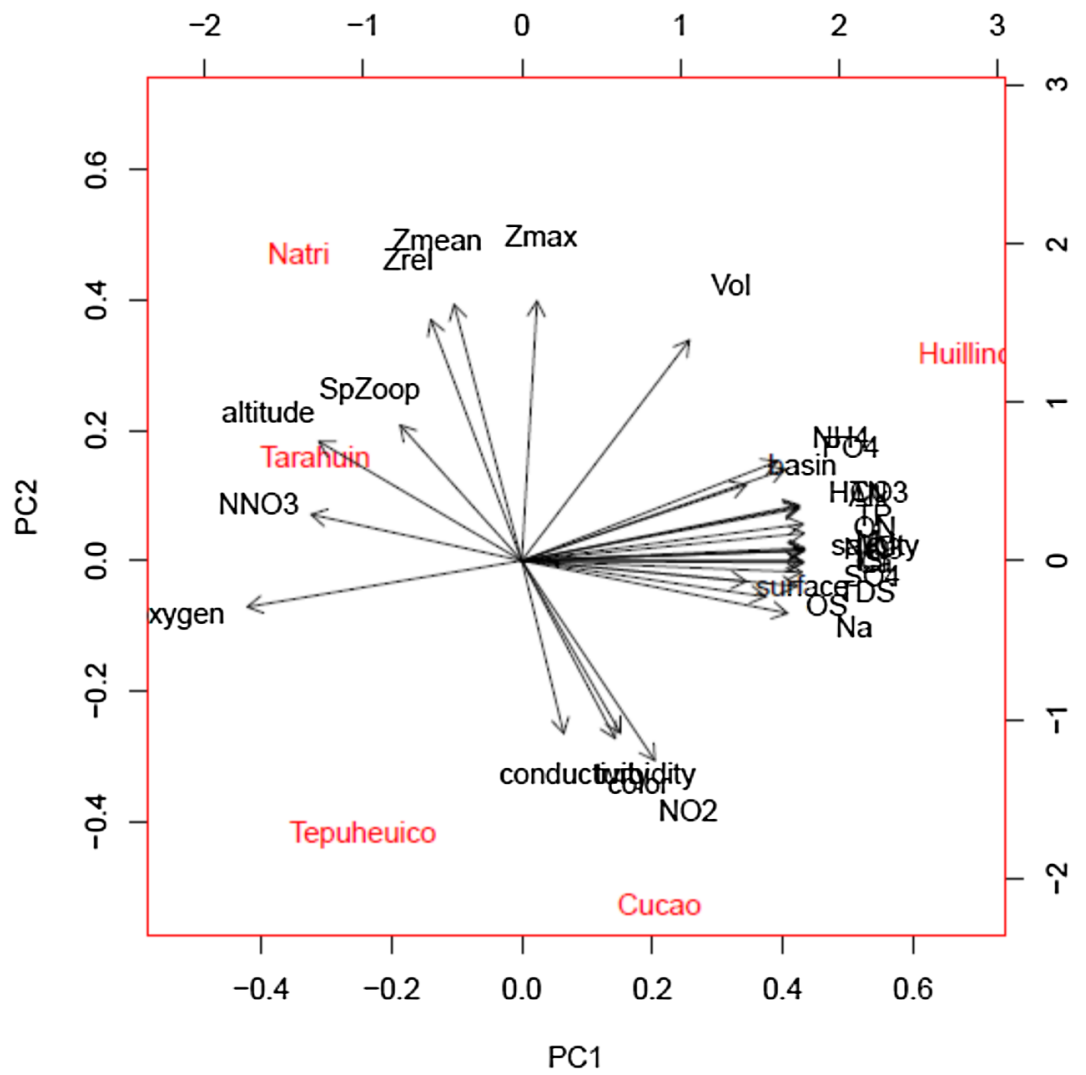

Fig. 2. Results of the PCA performed for the physico-chemical parameters of the studied sites. 


\section{TABLE II}

Contribution of variables for axis 1 and axis 2 in the PCA performed on the physico-chemical parameters as well as the numbers of crustacean zooplankton species of the five sites studied

\begin{tabular}{|c|c|c|}
\hline & Axis 1 & Axis 2 \\
\hline Altitude (m a.s.l.) & -0.15 & 0.18 \\
\hline Surface $\left(\mathrm{km}^{2}\right)$ & 0.16 & -0.06 \\
\hline $\operatorname{Basin}\left(\mathrm{km}^{2}\right)$ & 0.16 & 0.08 \\
\hline Maximum depth $\left(Z_{\max }\right)(m)$ & 0.01 & 0.37 \\
\hline Mean depth $\left(\mathrm{Z}_{\text {mean }}\right)(\mathrm{m})$ & -0.04 & 0.38 \\
\hline Relative depth $\left(\mathrm{Z}_{\mathrm{rel}}\right)(\mathrm{m})$ & -0.06 & 0.36 \\
\hline Volume $\left(\mathrm{km}^{3}\right)$ & 0.12 & 0.31 \\
\hline Colour (Platinum-Cobalt units) & 0.06 & -0.29 \\
\hline Turbidity (mg/l) & 0.06 & -0.28 \\
\hline $\mathrm{pH}$ & 0.13 & 0.15 \\
\hline Conductivity (mS/cm) & 0.03 & -0.22 \\
\hline Salinity $(\mathrm{g} / \mathrm{l})$ & 0.21 & -0.01 \\
\hline Total dissolved solids (mg/l) & 0.20 & -0.03 \\
\hline Oxygen $(\mathrm{mg} / \mathrm{l})$ & -0.21 & -0.07 \\
\hline $\mathrm{N}-\mathrm{NO}_{3}-(\mu \mathrm{g} / \mathrm{l})$ & -0.16 & 0.13 \\
\hline $\mathrm{NO}_{3}^{-}(\mu \mathrm{g} / \mathrm{l})$ & 0.21 & 0.03 \\
\hline $\mathrm{N}-\mathrm{NO}_{2}-(\mu \mathrm{g} / \mathrm{l})$ & 0.10 & -0.27 \\
\hline $\mathrm{N}-\mathrm{NH}_{4}+(\mu \mathrm{g} / \mathrm{l})$ & 0.19 & 0.13 \\
\hline Organic nitrogen $(\mu \mathrm{g} / \mathrm{l})$ & 0.21 & 0.03 \\
\hline Total nitrogen $(\mu \mathrm{g} / \mathrm{l})$ & 0.20 & 0.07 \\
\hline $\mathrm{P}-\mathrm{PO}_{4}{ }^{3-}(\mu \mathrm{g} / \mathrm{l})$ & 0.19 & 0.12 \\
\hline Total phosphorus $(\mu \mathrm{g} / \mathrm{l})$ & 0.21 & 0.04 \\
\hline Organic seston $(\mathrm{mg} / \mathrm{l})$ & 0.18 & -0.05 \\
\hline Inorganic seston $(\mathrm{mg} / \mathrm{l})$ & 0.21 & 0.01 \\
\hline Calcium $(\mathrm{Ca}, \mathrm{mg} / \mathrm{l})$ & 0.21 & -0.01 \\
\hline Magnesium (Mg, mg/l) & 0.21 & 0.01 \\
\hline Sodium $(\mathrm{Na}, \mathrm{mg} / \mathrm{l})$ & 0.20 & -0.07 \\
\hline Potassium (K, mg/l) & 0.21 & 0.01 \\
\hline Chloride $(\mathrm{Cl}, \mathrm{mg} / \mathrm{l})$ & 0.21 & -0.01 \\
\hline Sulfate $\left(\mathrm{SO}_{4}{ }^{2-}, \mathrm{mg} / \mathrm{l}\right)$ & 0.21 & -0.01 \\
\hline Bicarbonate $\left(\mathrm{HCO}_{3}{ }^{-}, \mathrm{mg} / \mathrm{l}\right)$ & 0.20 & 0.07 \\
\hline Alkalinity & 0.21 & 0.07 \\
\hline Number of species & -0.09 & 0.20 \\
\hline
\end{tabular}

The results of the PCA also revealed that lakes Huillinco and Cucao are markedly different from the other three lakes, because both lakes have high mineral contents, a shallow depth, a low oxygen concentration, are situated at low altitude, and harbour a low number of crustacean zooplankton species (table I, fig. 2). A different situation occurs in the other three lakes, first for lakes Natri and Tarahuin, which are both relatively deep, are situated at high altitude, and show high concentrations of oxygen and nitrate; they have high numbers of crustacean 


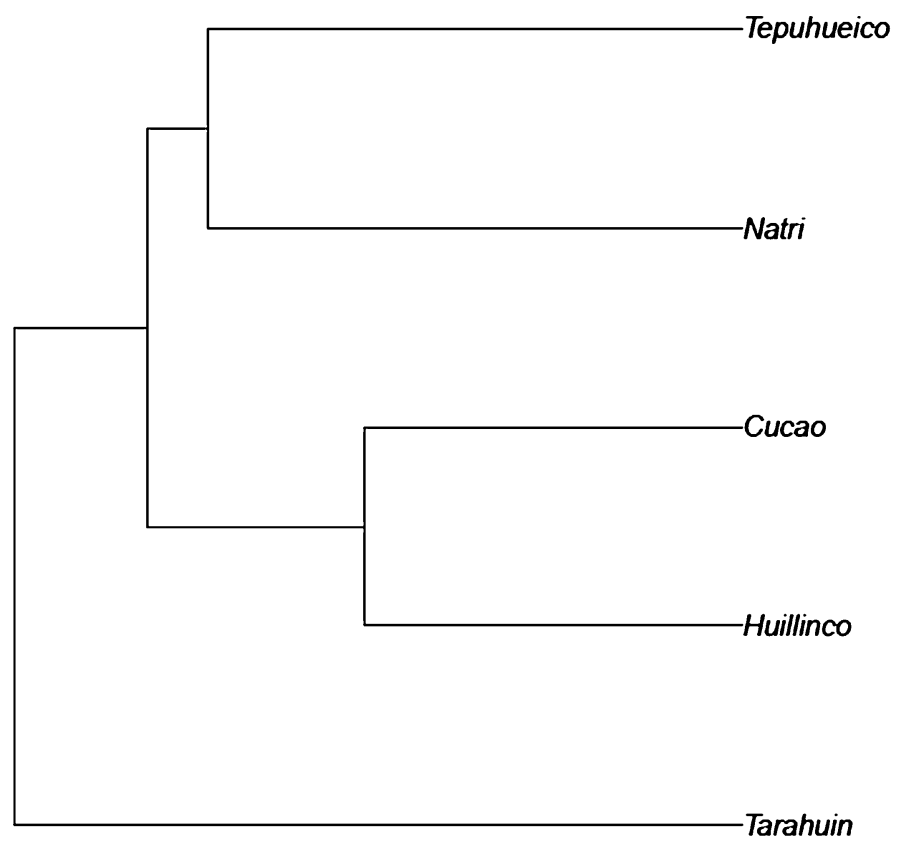

Fig. 3. Results of the UPGMA cluster analysis for the sites and crustacean species studied.

species (table I, fig. 2). Finally, for Tepuhueico lake, this has a low number of crustacean species, a high conductivity and a relatively shallow depth, as well as a low concentration of nutrients (table I, fig. 2).

These results would partially agree with the UPGMA, which revealed that the most similar lakes are Cucao and Huillinco, that are joined by a second group consisting of lakes Natri and Tepuhueico, and to conclude the most different appeared to be Tarahuin lake (fig. 3). Finally, the results of the co-occurrence species null model revealed the absence of any regulatory patterns (Mean index $=$ 0.883 ; Observed index $=0.923 ; P=0.15$ ), which would not agree with the cluster analysis.

\section{DISCUSSION}

As exposed by the above results, a different pattern in zooplankton species composition and their respective regulator factors would apply to these Chiloé Island lakes in comparison to the earlier observations on Argentinean and Chilean Patagonian, as well as New Zealand lakes, where only oligotrophy would be the main regulator factor of crustacean species numbers (Soto \& Zúniga, 1991; Jeppensen et al., 1997; Modenutti et al., 1998; Woelfl, 2007; De los Ríos-Escalante, 2016). 
The results obtained in the present study revealed the probable role of marine influence, as indicated by the high mineral contents of lakes Cucao and Huillinco, which are close to, and even connected to, the Pacific coast. These two lakes have a low number of crustacean species, in comparison with the other lakes that are connected indirectly to the Pacific Ocean by effluent rivers (Campos, 1997; Villalobos et al., 2003). Although the literature revealed the role of a combined effect between chlorophyll $a$ concentration and salinity as a regulator of crustacean zooplankton assemblages in southern Patagonian lakes that show marked marine influence due to strong winds (Soto \& De los Ríos, 2006), the results obtained in the present study would be different, because the lakes Cucao and Huillinco are interconnected, and Lake Cucao has an effluent river to the Pacific Ocean (Campos, 1997; Villalobos et al., 2003).

As regards species composition, the species found (table I) are similar to those reported for Chilean northern Patagonian lakes, and these species are widespread among many lakes (Soto \& Zúñiga, 1991; De los Ríos-Escalante, 2016). In this scenario, under a mesotrophic status, this system of two lakes and a river discharging into the Pacific, would exhibit a marked increase in species number, in the same sense as has been reported for northern Patagonian lakes (Woelfl, 2007), with the same species occurring in many of the water bodies under study (De los Ríos-Escalante, 2016). This condition would agree with the results of the null model analysis. In this case, a similar situation would probably be enhanced by additional river connections of some lakes and lagoons on Chiloé Island, such as lakes Cucao and Huillinco (fig. 1; Campos,1997; Villalobos et al., 2003).

An inverse relationship between number of crustacean species and salinity has been reported for saline lakes (Anton-Pardo \& Armengol, 2012; Gutkowska et al., 2012; Ginatullina et al., 2017; Hemraj et al., 2017), and salinity can have a combined effect with the lake's trophic status in terms of nutrients increasing in coastal lakes (Whitman et al., 2004), which would agree with the results obtained in the present study. Also, a similar result has been reported for data from connected coastal lagoons in Indonesia (Pratiwi et al., 2016). In this scenario, the results obtained for the lakes on Chiloé Island would agree with similar results reported in the literature, and it would be necessary to do more studies, i.e., also for other Chilean coastal lakes that have a coastal and estuarine connection by effluent rivers.

The assessment and monitoring of the ecosystem components changes both in the inland and in the coastal waters of Chile, under a combination of stressor scenarios. In the case of the spatial distribution of zooplankton, no study has yet been conducted on the use of these organisms as trophic indicators. Nonetheless, linking the pelagic ecosystems of the catchment basins and the lakes on Chiloé more broadly with other water bodies in Chile is a necessary tool for sustainable 
management. Obviously, viz., linking the Integrated Environmental Management to the Integrated Coastal Zone Management (IEM-ICZM), to achieve a Good Environmental Status (GEnS), which is the main objective of the Water Framework Directive (WFD), requires reliable data on the physico-chemical as well as the biological characteristics of the components, i.e., rivers, lakes, and lagoons in the entire area.

\section{ACKNOWLEDGEMENTS}

The present study was funded by the projects Tides Grant Foundation TRF1303011 and MECESUP UCT 0804, and by the Research Direction of the Catholic University of Temuco. We also thank M.I for her valuable comments for improving the manuscript.

\section{REFERENCES}

Anton-Pardo, M. \& X. Armengol, 2012. Effects of salinity and water temporality on zooplankton community in coastal Mediterranean ponds. Est. Coast. Shelf Sci., 114: 93-99.

Campos, H., 1997. Determinación de la capacidad de carga y balance de fósforo y nitrógeno de los lagos Natri, Cucao, Huillinco, Tepuhueico y Tarahuin. Technical Report Fisheries Research Foundation — Chile, FIP-IT/96-54 Vol. 1 [In Spanish.]

De Los Ríos-Escalante, P., 2016. Null models for study rotifers and crustacean zooplankton species richness in Chilean Patagonian lakes. Act. Limnol. Bras., 28: e11.

EveritT, B. S. \& T. Hothorn, 2016. A handbook of statistical analysis using R, 1st edn. Available online at: https://cran.r-project.org/web/packages/HSAUR/HSAUR.pdf (accessed 13 July 2016).

Ginatullina, E., L. Atwell \& L. Saito, 2017. Resilence and resistence of zooplankton communities to drought-induced salinity in freshwater and saline lakes of central Asia. J. Arid Env., 144: 1-11.

GotelLi, N. J., 2000. Null models of species co-occurrence patterns. Ecology, 81: 2606-2621.

Gotelli, N. J. \& G. L. EntSminger, 2007. EcoSim: Null models software for ecology. Version 7. Available online at: http://garyentsminger.com/ecosim.htm (Acquired Intelligence \& KeseyBear, Jericho, VT).

Gotelli, N. J. \& A. M. ElLison, 2013. EcoSimR 1.00. Available online at: http://www.uvm.edu/ $\sim$ ngotelli/EcoSim/EcoSim.html.

Gutkowska, A., E. Paturej \& E. Kowalska, 2012. Qualitative and quantitative methods for sampling zooplankton in shallow coastal estuaries. Ecohydrol. Ecohydrobiol., 12: 253-263.

Hauenstein, E., M. González, F. Peña-Cortés \& A. Muñoz-Pedreros, 2002. Clasificación y caracterización de la flora y vegetación de los humedales de la costa de Toltén (IX Región, Chile). Gayana Bot., 59: 87-100.

Hemraj, D. A., M. A. Hossain, Q. Ye, J. G. Qin \& S. C. Leterme, 2017. Plankton bioindicators of environmental conditions in coastal lagoons. Est. Coast. Shelf Sci., 184: 102114.

Jeppensen, E., T. L. Lauridsen, S. F. Mitchell \& C. W. Burns, 1997. Do zooplanktivorous fish structure the zooplankton communities in New Zealand lakes? New Zealand J. Mar. Freshwat. Res., 31: 163-173. 
Modenutti, B. E., E. G. Balseiro, C. P. Queimaliños, D. A. Añón Suárez, M. C. DiegueZ \& R. J. AlbARIÑo, 1998. Structure and dynamics of food webs in Andean lakes. Lakes Reserv. Res. Manag., 3: 179-189.

Pratiwi, N. T. M., A. Ardhito, D. Y. Wulandari \& A. Iswantari, 2016. Horizontal distribution of zooplankton in Tangerang coastal waters, Indonesia. Proceedia, Env. Sci., 33: 470-477.

R Development CoRe TeAm, 2009. R: a language and environment for statistical computing. (R Foundation for Statistical Computing, Vienna).

SCHLIEP, K. P., 2011. Phangorn: phylogenetic analysis in R. Bioinformatics, 27: 592-593.

Soto, D. \& P. DE LOS Rios, 2006. Trophic status and conductivity patterns as regulators in daphnids dominance and zooplankton assemblages in lakes and ponds of Torres del Paine National Park. Biologia Bratislava, 61: 541-546.

Soto, D. \& L. R. ZUÑIGA, 1991. Zooplankton assemblages of Chilean temperate lakes: a comparison with North American counterparts. Rev. Chilena Hist. Nat., 64: 569-581.

TIHO, S. \& G. JosENS, 2007. Co-occurrence of earth worms in urban surroundings: a null model analysis of community structure. Eur. J. Soil Biol., 43: 84-90.

TONDOH, J. E., 2006. Seasonal changes in earthworm diversity and community structure in central Côte d'Ivoire. Eur. J. Soil Biol., 42: s334-s340.

Villalobos, L., O. Parra, M. Grandjean, E. Jaque, S. Wölfl \& H. Campos, 2003. River basin and limnological study in five humic lakes of the Chiloé Island. Rev. Chilena Hist. Nat., 76: $10-15$.

Whitman, R. L., M. B. Nevers, M. L. Goodrich, P. C. Murphy \& B. M. Davis, 2004. Characterization of Lake Michigan coastal lakes using zooplankton assemblages. Ecol. Indic., 4: $277-286$.

Woelfl, S., 2007. The distribution of large mixotrophic ciliates (Stentor) in deep north Patagonian lakes (Chile): first results. Limnologica, 37: 28-36.

First received 18 August 2017.

Final version accepted 19 November 2017. 